\title{
Strategi Dalam Meningkatkan Mutu Pendidikan di Sekolah
}

\author{
Sukma \\ Universitas Negeri Padang \\ Indonesia \\ E-mail : sukma980513@gmail.com
}

\author{
Rusdinal \\ Universitas Negeri Padang \\ Indonesia \\ E-mail : rusdinal@gmail.com
}

\author{
Hade Afriansyah \\ Universitas Negeri Padang \\ Indonesia \\ E-mail : \\ hadeafriansyah@fip.unp.ac.id
}

\begin{abstract}
Abstrak-- There have been many efforts made by the government in improving the quality of education such as issuing Republic of Indonesia Regulation No. 19 of 2005 concerning national education standards. Educational institutions hold scientific activities that can improve the ability or potential of educators so that professional educators can be created who can later improve the quality of learning in schools. This article discusses the factors that can improve the quality of education, elements and strategies in improving the quality of education.
\end{abstract}

Kata Kunci: Mutu, Pendidikan, Sekolah

\section{Pendahuluan}

Pendidikan menjadi faktor utama dalam membentuk kepribadian manusia. Pendidikan dapat membuat perubahan kea rah yang lebih baik bagi manusia. Baik dari segi pola piker maupun dari segi tingkah laku. Pendidikan dapat membuat seseorang dapat menjalankan kehidupannya dalam bermasyarakat berbangsa dan bernegara. Upaya dalam meningkatkan mutu pendidikan, pemerintah mengeluarkan PP RI No 19 tahun 2005 tentang standard nasional pendidikan. Dimana dalam peraturan tersebut berisi proses pembelajaran dalam pendidikan dilakukan secara saling berhubungan, inspirasi, menyenangkan, menantang serta menumbuhkan motivasi peserta didik berpartisipasi dalam pembelajaran. pendidik dituntut agar dapat menjadi teladan atau menjadi sebagai panutan bagi peserta didik. setiap lembaga pendidikan harus melakukan rencana proses dari pembelajaran, melaksanakan proses pembelajaran, memberi penilaian dari hasil pembelajaran, serta mengawasi proses pembelajaran.

TQM adalah suatu bentuk keinginan untuk selalu mencoba sesuatu dengan selalu baik. TQM menekankan bahwa setiap orang yang ada dalam suatu organisasi wajib telibat dalam peningkatan organisasinya tersebut. Kata manajemen artinya setiap orang dalam organisasi adalah manajer untuk bidang yang menjadi tanggung jawabnya.

\section{Metode Penelitian}

Penelitian ini menggunakan metode pengamatan beserta data yang berkaitan mengenai kualitas atau mutu pendidikan yang ada pada pendidikan di Indonesia. Dimana hasil pengamatannya yaitu sudah banyak upaya pemerintah dalam menangani masalah pendidikan di Indonesia. Salah satu upaya yaitu meningkatkan mutu pendidikan, pemerintah mengeluarkan PP RI No 19 tahun 2005 tentang standard nasional pendidikan..

\section{KAJIAN TEORI DAN PEMBAHASAN}

Bagian ini merupakan bagian inti dari penulisan artikel. Karena bagian ini memuat bahan kajian dan pembahasan teori yang diteliti. Perhatikan aturan penomorannya. Sebagai contoh:

\section{A. Faktor Dalam peningkatan mutu pendidikan}

\section{1) Pimpinan (kepsek)}

kepsek harus memahami visi kerja secara jelas serta mampu dan mau bekerja keras, mempunyai dorongan yang besar dalam bekerja serta menjadi teladan atau contoh bagi para bawahannya.

\section{2) Pendidik}

meningkatkan potensi serta keprofesionalan pendidik dalam mengajar sehingga nanti tercapainya tujuan dari pendidikan.

\section{3) Peserta Didik}

pendidik harus bisa melakukan interaksi atau pendekatan kepada peserta didik agar kemampuan dari peserta didik dapat dikenali dan pendidik dapat menggali serta mengembangkan bakat dan kemampuan peserta didik.

4) Kurikulum

kurikulum yang sesuai dapat memungkinkan dan memudahkan tercapainya standard mutu pendidikan yang diharapkan.

\section{5) Kerjasama}

kerjasama tidak hanya ada pada lingkungan sekolah dan masyarakat serta orang tua saja, tetapi juga dengan organisasi lain sehingga lulusan dari sekolah dapat berguna dalam dunia kerja. 


\section{B. Syarat Pendidik}

1) Pendidik harus bisa menggunakan metode atau variasi metode dalam pembelajaran agar peserta didik dapat dengan mudah memahami pembelajaran yang disajikan.

2) Pendidik harus bisa menumbuhkan motivasi peserta didik dalam belajar. Jika pendidik mampu menumbuhkan motivasi peserta didik, maka peserta didik akan lebih tekun dan lebih bersemangat dalam belajar.

\section{Beberapa Hal Penting yang Dapat Meningkatkan Mutu Pembelajaran}

\section{1) Mutu}

sekolah harus bisa menjadi tempat yang unggul dalam pembelajaran, dengan visi misi yang jelas serta upaya ke arah perbaikan mutu pendidikan.

2) Aspek peningkatan mutu, partisipasi peserta didik, pendidik serta orang tua.

3) Faktor utama dalam peningkatan mutu, pendidik dan tenaga pendidikan yang professional, fasilitas yang memadai serta partisipasi peserta didik dan orang tua dalam program sekolah.

4) Program penunjang perbaikan mutu, program penunjangnya yaitu kurikulum yang berlaku.

\section{Peningkatan Mutu Pendidikan Melalui Pembelajaran}

Pembelajaran harus melibatkan proses berfikir dan dalam proses pembelajaran membangun suasana dialogis serta tanya jawab guna meningkatkan kemampuan berfikir siswa sehingga membantu siswa untuk memperoleh pengetahuan. Proses pembelajaran dapat dilakukan oleh peserta didik baik dalam ruangan maupun diluar ruangan. Pembelajaran menurut konstruktivisme yaitu pembelajaran dibangun oleh manusia, yang hasilnya nanti diperluas seiring berkembangnya zaman serta pengalaman yang nyata. Pendekatan konstruktivisme dalam pembelajaran berpusat pada siswa. Pendidik dituntut untuk dapat menciptakan suasana belajar yang sedemikian rupa agar siswa tidak mudah jenuh dan bosan saat belajar.

\section{E. Unsur penting dalam peningkatan mutu pembelajaran}

1) Pendekatan mikro, pendekatan terhadap pendidikan kepada peserta dalam pembelajaran.

2) Pendekatan makro, pendekatan makro pendidikan yaitu kajian pendidikan dengan standard pengembangan kurikulum, pemerataan, persamaan dan keadilan, standard mutu dan kemampuan bersaing.

\section{KESIMPULAN}

Pendidik menjadi faktor utama dalam membentuk kepribadian manusia. Pendidikan dapat membuat perubahan kearah yang lebih baik bagi manusia. Baik dari segi pola piker maupun dari segi tingkah laku. Pendidikan dapat membuat seseorang dapat menjalankan kehidupannya dalam bermasyarakat berbangsa dan bernegara. Upaya dalam meningkatkan mutu pendidikan, pemerintah mengeluarkan PP RI No 19 tahun 2005 tentang standard nasional pendidikan. Dimana dalam peraturan tersebut berisi proses pembelajaran dalam pendidikan dilakukan secara saling berhubungan, inspirasi, menyenangkan, menantang serta menumbuhkan motivasi peserta didik berpartisipasi dalam pembelajaran. Pendidik dituntut agar dapat menjadi teladan atau menjadi sebagai panutan bagi peserta didik. Setiap lembaga pendidikan harus melakukan rencana proses dari pembelajaran, melaksanakan proses pembelajaran, memberi penilaian dari hasil pembelajaran, serta mengawasi proses pembelajaran.

(Strategi Peningkatan Mutu Pendidikan di Sekolah, 2012)

\section{DAFTAR PUSTAKA}

Saifulloh, M., Muhibbin, Z., \& Hermanto. (2012). Strategi Peningkatan Mutu Pendidikan Di Sekolah. Jurnal Sosial Humaniora, 5(2), 206-217.

Fauzi, H. (2017). Kurikulum 2013 Untuk Total Quality Education di Indonesia. Tarbawi, 14(2), 147-160. 